\title{
Sodium Chloride-Induced Leaf Senescence in Hydrocotyle bonariensis Lam. and Foeniculum vulgare $\mathrm{L}$.
}

\author{
Claudia R. B. Haddad ${ }^{1 *}$ and Paulo Mazzafera ${ }^{1}$ \\ ${ }^{l}$ Departamento de Fisiologia Vegetal, IB, UNICAMP, Caixa Postal 6109, CEP 13083-970, Campinas - SP, Brazil.
}

\begin{abstract}
Leaf senescence induced by sodium chloride was studied in Hydrocotyle bonariensis Lam. and Foeniculum vulgare L. Both species belong to Umbelliferae family, however only H. bonariensis grows spontaneously in sandy soils of coastal regions (saline soils). Leaves of plants receiving nutrient solutions containing different concentrations of $\mathrm{NaCl}$ were evaluated for fresh and dry weights and chlorophyll content. The denaturating electrophoretic profiles of leaf proteins were also studied. Sodium chloride changed the protein profile of $F$. vulgare and hastened the leaf senescence of both the species. However, plants of $H$. bonariensis receiving $599 \mathrm{mM} \mathrm{NaCl} \mathrm{lasted} \mathrm{longer} \mathrm{than} F$. vulgare. Therefore, the occurrence of $H$. bonariensis in saline soils might be related with mechanisms of salinity tolerance.
\end{abstract}

Key words: chlorophyll; protein; salinity; senescence.

\section{INTRODUCTION}

Excess of salts in the soil may reduce the growth and production of many plants. Soil may be saline for several reasons including flooding of the coastline with sea water. The sea water has approximately $599 \mathrm{mM} \mathrm{NaCl}$ (Mc Intyre, 1982). Therefore, in coastline the salt negative effect in plant development may be mainly attributed to $\mathrm{NaCl}$.

Based on their salt tolerance, the plants can be classified as halophytes or glycophytes. In general while halophytes can complete their life cycle in saline environment, glycophytes can not. The existence of some species in saline habitats does not necessarily mean that $\mathrm{NaCl}$ is essential for their growth and development, although some species can not survive without $\mathrm{NaCl}$ (Wainwright, 1984).

Besides inducing a decline in growth, high concentrations of $\mathrm{NaCl}$ hasten the senescence of several crops (Helmy et al, 1994; Lutts et al, 1996; Munns et al, 1995; O'Leary \& Prisco, 1970a; Prisco \& O'Leary, 1972; Prisco, 1980; Sharma, 1996), most of them being glycophytes
(Wainwright, 1984). Jackson and Drew (1984) described $\mathrm{NaCl}$ as one of the factors promoting leaf senescence.

Leaf senescence is a highly-controlled sequence of events comprising the final stage of development, from mature, fully expanded state until death. As a leaf passes the peak of assimilatory capacity, the photosynthetic apparatus is dismantled and the nutrients are exported to young growing tissues or storage organs (Smart, 1994). Moreover, there is a fall in the chlorophyll content (Matile et al, 1989, 1992), changes in the pattern of protein synthesis (Thomas et al, 1992) and a decrease in the protein concentration (Smart, 1994).

Hydrocotyle bonariensis Lam. is a member of the Umbelliferae family. It has an underground shoot that is connected with the leaves by long petioles. This species has a large distribution including saline coastal soils, what might be an indication that it is a halophyte.

Foeniculum vulgare L. is largely used as a spice. It also belongs to the Umbelliferae family. However, it is not found in saline coastal soils.

\footnotetext{
* Author for correspondence
} 
The objective of this work was to compare the influence of sodium chloride on the leaf senescence of these two species.

\section{MATERIALS AND METHODS}

Plant material and growth conditions: Cuttings of $H$. bonariensis with only one leaf connected by the petiole to the part of an underground shoot were obtained from plants growing in clay soil (44\% clay and $12.7 \%$ siltYamaoka-Yano \& Mazzafera, 1998). These cuttings had very young leaves, still unfolded, with average leaf blade fresh and dry weights of 46 and $6 \mathrm{mg}$ (average of 10 leaves), respectively. The petiole and rhizome length were 4.5 and $3 \mathrm{~cm}$, respectively. The apical region of the rhizome was removed to avoid a sink effect of the nutrients from the leave to the active growing tissue that could accelerate the leaf senescence. All the leaves appearing later in these cuttings were removed for the same reason. The cuttings were washed in a $0.2 \%$ sodium hypochloride solution for 2 min before planting.

The $F$. vulgare plants grew from seeds. Only their primary leaves were submitted to chlorophyll, protein and growth analyses.

At the time of the experiments, $F$. vulgare plants were 15 days old and $H$. bonariensis cuttings were 10 days old. The plants, unless indicated, were grown in $1.5 \mathrm{~L}$ pots with sand, kept in the greenhouse. They were weekly irrigated with Hoagland nutrient solution (Hoagland \& Arnon, 1938) up to the saturation point, or received the same nutrient solution with added $\mathrm{NaCl}$ so that the final salt concentration was 257 or $599 \mathrm{mM}$. One day before the application of the solutions, the sand of the pots was washed with tap water to avoid the accumulation of salt above the established values. The same was made with the pots receiving only nutritive solution (control treatment).

The plants used for the evaluation of the effect of sodium chloride on the protein electrophoretic profile were transferred from pots with sand to hydroponic solution under photoperiod of 12 hours (light/dark) and average temperature of $25^{\circ} \mathrm{C}$. They grew up in Hoagland solution with or without added $\mathrm{NaCl}(259 \mathrm{mM})$. The solution was replaced weekly and between the changes, the solution levels in the pots were maintained by the addition of destilled water.

Leaf growth: The leaf dry and fresh weights were obtained every 10 days from 10 replicates growing in sand. Dry weight measures were obtained keeping the leaves at $80^{\circ} \mathrm{C}$ for $24 \mathrm{~h}$.

Chlorophyll: The chlorophyll contents in the leaves were obtained every 10 days from 3 replicates growing in sand. Chlorophyll was extracted with $95 \%$ ethanol at $60^{\circ} \mathrm{C}$ and the absorbances at 645 and $665 \mathrm{~nm}$ were used to determine the chlorophyll concentration (Lichtenthaler \& Wellburn, 1983).

Protein electrophoretic profile: Three replicates were used in this experiment. Leaves of both species were homogenized in a mortar with cold $\left(4^{\circ} \mathrm{C}\right) 50 \mathrm{mM}$ phosphate buffer $(\mathrm{pH} 7)$, containing $5 \mathrm{mM}$ 2-mercaptoethanol. The extracts were centrifuged at $27,200 \mathrm{~g}$ for $15 \mathrm{~min}$ and the supernatants were recovered. The protein concentrations were determined (Bradford, 1976) and the extracts were diluted $(1: 1, \mathrm{v} / \mathrm{v})$ with $50 \mathrm{mM}$ phosphate buffer $(\mathrm{pH} 7)$, containing $5 \mathrm{mM}$ 2-mercaptoethanol, 1\% SDS and 5\% glycerol. Protein denaturation was carried out at $100^{\circ} \mathrm{C}$ for $10 \mathrm{~min}$ and the extracts were stored at $-20^{\circ} \mathrm{C}$ for electrophoretic analysis. The proteins were separated by denaturating polyacrylamide gel electrophoresis - SDS-PAGE (Laemmlli, 1970), using 6\% of polyacrylamide in the stacking gel and $12 \%$ in the main gel. The same amount of proteins was applied in the gels for both the species. Ovalbumin, bovine serum albumin, chymotrypsin and ribonuclease A were used as molecular weight markers. Proteins were stained with Comassie Blue R250.

$\mathrm{Na}$ and $\mathrm{Cl}$ concentration in the soil: Samples of sandy (quartz) coastal soils of two localities (São Sebastião and Ubatuba, São Paulo State) were analyzed for their $\mathrm{Na}$ and $\mathrm{Cl}$ contents (Bataglia et al, 1978). H. bonariensis was found growing naturally in both places. Sand was collect from the upper $20 \mathrm{~cm}$ layer. A sample of a clay soil (Yamaoka-Yano \& Mazzafera, 1998) was also collected from a place where $F$. vulgare and $H$. bonariensis grew spontaneously. 
In addition to this another analysis was made: $200 \mathrm{ml}$ of deionized water were added to $200 \mathrm{~g}$ of each soil and vigorously stirred. After sedimentation of the soil particles, the conductivity was determined using a conductivimeter. The values obtained were applied to a standard curve obtained with the data of $\mathrm{NaCl}$ deionized aqueous solutions at different concentrations.

\section{RESULTS}

$\mathrm{NaCl}$ affected the first leaf life span of the 15 days old plants of $F$. vulgare (Figure 1A). The leaves of plants irrigated with $599 \mathrm{mM} \mathrm{NaCl}$
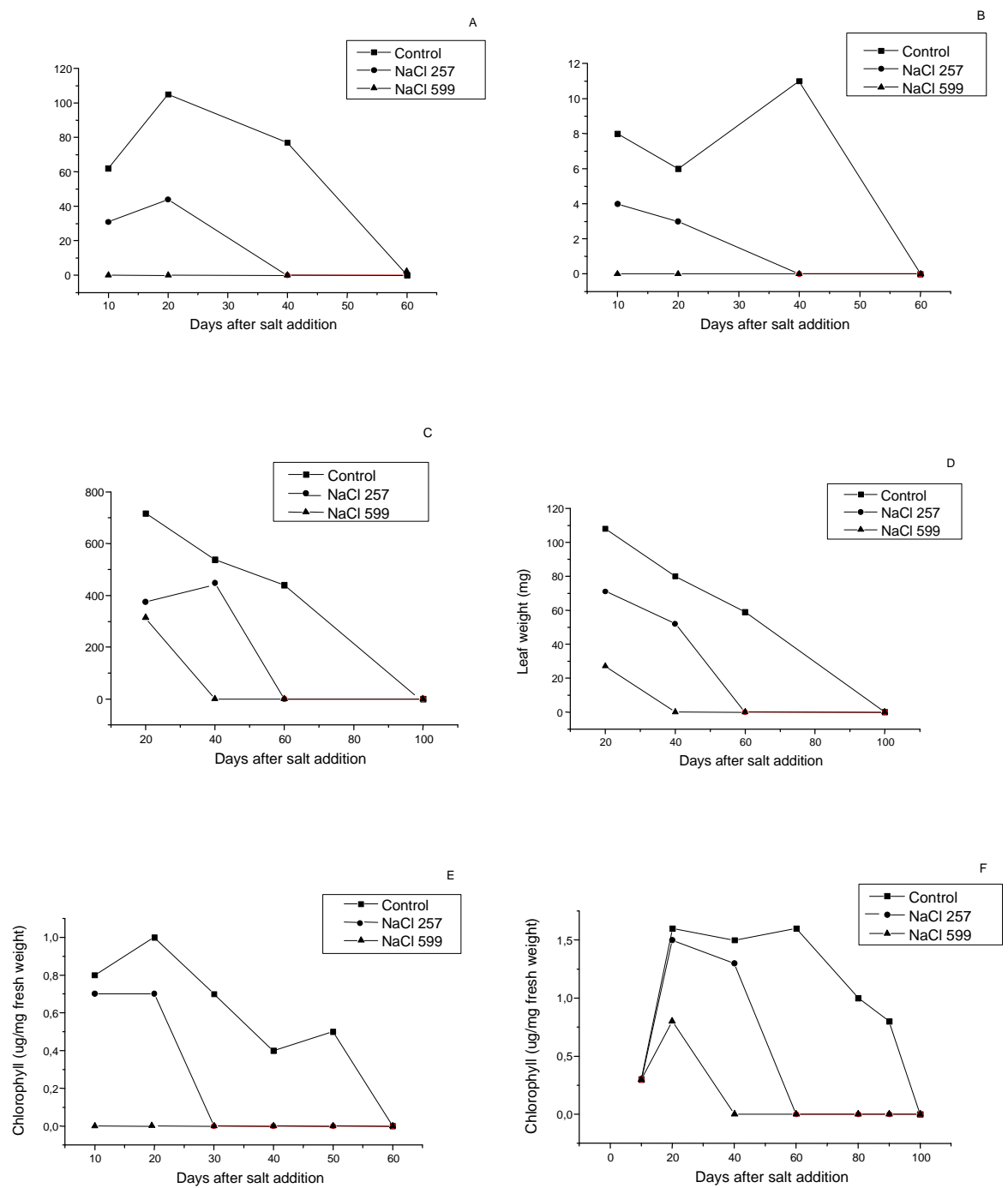

Figure 1: Fresh weight (A) and dry weight (B) of of leaves of $F$. vulgare, fresh weight $(\mathrm{C})$ and dry weight of leaves of $H$. bonariensis and chlorophyll contents of leaves of $F$. vulgare $(\mathrm{E})$ and $H$. bonariensis $(\mathrm{F})$ treated or not with $\mathrm{NaCl}$ at 257 and $599 \mathrm{mM}$. died before the first measurement at 10 days. Leaves of plants irrigated with $257 \mathrm{mM} \mathrm{NaCl}$ lasted longer (20 days), but with a marked decrease of fresh and dry weight. The death of leaves of the control plants occurred only at 60 days and the highest fresh weight (Figure 1A) and dry weight (figure 1B) were observed in these plants at 20 and 40 days, respectively.

When the cuttings of $H$. bonariensis were transfered to the sand pots the leaves had 46 and $6 \mathrm{mg}$ of fresh and dry weight, respectively. After 10 days, they received the first salt irrigation. 
The highest fresh and dry weights of control leaves were observed at 20 days of the salt addition and death occurred at 100 days (Figure 1C and D, respectively). Plants of $H$. bonariensis, irrigated with salt showed reduction of leaf growth at both concentrations, however leaves of those receiving $257 \mathrm{mM}$ $\mathrm{NaCl}$ lived longer than those of $599 \mathrm{mM}$. It was interesting to observe that leaves of plants irrigated with $599 \mathrm{mM}$ survived more than 20 days after the first salt addition, resulting in an increase in fresh and dry weights when compared with the cutting leaves at the transplantation.

The highest chlorophyll content in the leaves of the control plants of $F$. vulgare was observed at 20 days (Figure 1E), indicating that after this period the senescence had been established in these plants. This is in agreement with the observed decrease in fresh weight (figure 1A), and happened before the decrease in dry weight (Figure 1B). The leaves of plants irrigated with $257 \mathrm{mM} \mathrm{NaCl}$ always showed lower chlorophyll contents than the control plants.

The chlorophyll contents in leaves of $H$. bonariensis were higher between 20 and 60 days (Figure 1F), although a decrease in the fresh and dry weights was observed in this period (Figure $1 \mathrm{C}$ and $1 \mathrm{D}$, respectively). The opposite situation was observed in $F$. vulgare. In the leaves of plants receiving $599 \mathrm{mM} \mathrm{NaCl}$ (Figure 1F), the chlorophyll contents were lower than in the leaves of plants irrigated with $257 \mathrm{mM} \mathrm{NaCl}$. Therefore, dry weight and chlorophyll content seem to be good indicators of salt-induced senescence.

The protein electrophoretic profiles were obtained from plants growing in hydroponics (Figure 2). The leaves of $H$. bonariensis were collected after 15 days of transfer to hydropony. On the other hand, the leaves of $F$. vulgare were collected just after 1 day, since at this time they already started to become yellow in the presence of $257 \mathrm{mM} \mathrm{NaCl}$. While there was not any alteration in the number of bands of protein extracts from leaves of $H$. bonariensis irrigated with $257 \mathrm{mM} \mathrm{NaCl}, 3$ bands desappeared in $F$. vulgare salt treated plants. Also, in these plants a new band was observed.

Salt induced alterations in the protein concentrations were also observed. In salt treated $H$. bonariensis plants, there was an increase in the protein concentration of 2 bands. On the other hand, in $F$. vulgare a reduction in the protein concentration of 4 bands was detected.

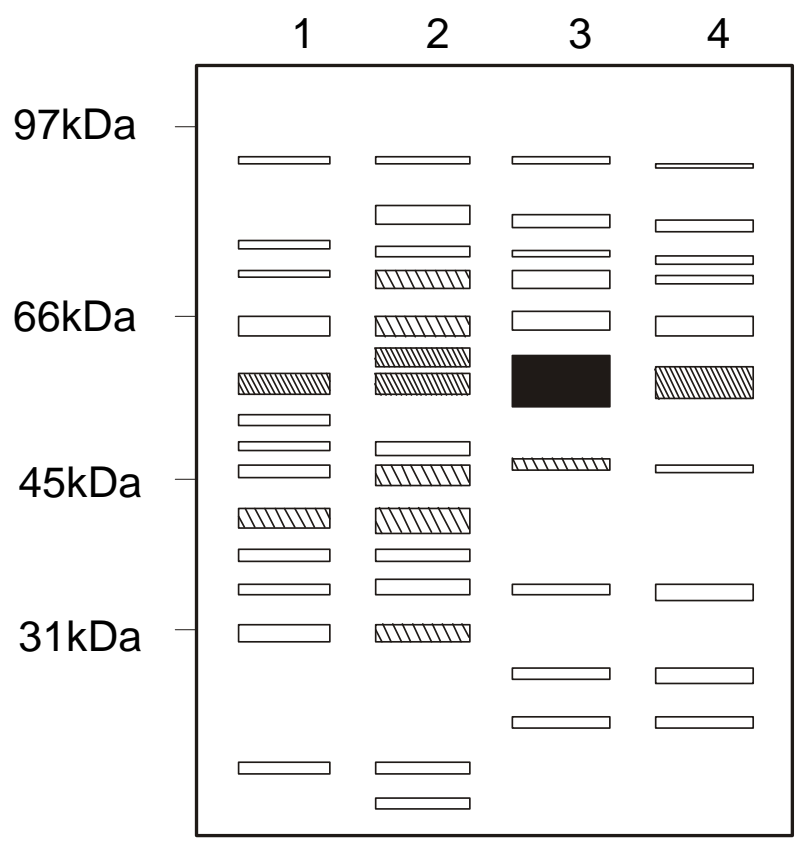

Figure 2: Schematic diagram of the eletrophoretic profile of proteins from $F$. vulgare primary leaves and $H$. bonariensis cuttings leaves, growing with or without $257 \mathrm{mM} \mathrm{NaCl}$ in the nutrient solution. $1=F$. vulgare $+\mathrm{NaCl}, 2=F$. vulgare $-\mathrm{NaCl}, 3=H$. bonariensis $+\mathrm{NaCl}$, and $4=H$. bonariensis $-\mathrm{NaCl}$. Molecular weight markers are indicated in the left side of the figure (ovalbumin $=97 \mathrm{kDa}$, bovine serum albumin $=66 \mathrm{kDa}$, chymotrypsin $=45 \mathrm{kDa}$, ribonuclease $\mathrm{A}=31 \mathrm{kDa}$ ).

About the analysis of $\mathrm{Na}$ and $\mathrm{Cl}$ concentrations in the soil samples, although São Sebastião soil was collected from the sea-coast, it showed $\mathrm{Na}$ and $\mathrm{Cl}$ concentrations and conductivity similar to the clay soil (Table 1). The sandy soil from Ubatuba had 10 times more $\mathrm{Na}$ and $\mathrm{Cl}$ than the other two samples. The results of $\mathrm{NaCl}$ concentration in these same soil samples, obtained with the use of conductivimeter are in agreement with these results: sand soil from 
Ubatuba presented $66 \mathrm{mM}$ of $\mathrm{NaCl}$, while the values for São Sebastião sand soil and the clay soil where $2 \mathrm{mM}$ and $3 \mathrm{mM}$, respectively.

Table 1: $\mathrm{Na}, \mathrm{Cl}$ and $\mathrm{NaCl}$ concentrations of three soil samples of two different kinds (sand and clay soil). São Sebastião and Ubatura are the places where sand soil was collected.

\begin{tabular}{|c|c|c|c|}
\hline \multirow[t]{2}{*}{ Soil Sample } & \multicolumn{2}{|c|}{ Ion Concentration (mM) } & \multirow{2}{*}{ NaCl Concentration (mM) } \\
\hline & $\overline{\mathrm{Na}}$ & $\overrightarrow{\mathrm{Cl}}$ & \\
\hline Sand soil-Ubatuba & 2850 & 4100 & 66 \\
\hline -S. Sebastião & 250 & 390 & 2 \\
\hline Clay soil & 220 & 385 & 3 \\
\hline
\end{tabular}

\section{DISCUSSION}

$\mathrm{NaCl}$ induced a decrease of fresh and dry weights and of chlorophyll contents in the leaves of $H$. bonariensis and $F$. vulgare. Similar results were observed in bean (O'leary \& Prisco, 1970a), wheat (Munns et al, 1995) and rice (Lutts et al, 1996). Therefore, our data supported the concept that the level of chlorophyll (Matile et al, 1992) and decrease of dry weight (Rabinowitch, 1951 apud Leopold \& Kriedmann, 1975) were good indicators of leaf senescence.

Changes of the protein profile due to $\mathrm{NaCl}$ have been reported for several species. In cell suspensions of Citrus sp and Nicotiana tabacum adapted to high salt concentrations, several new proteins were observed (Singh et al, 1987).

Protein concentration could also change with the presence of salt. $\mathrm{NaCl}$ inhibited protein synthesis of embrio-axis of germinating bean seeds (O'Leary \& Prisco, 1970b; Prisco, 1971) as well as induced decrease or increase of the proteins in leaves of different rice and soybean cultivars (Abd el-Samad \& Shaddad, 1997; Lutts et al, 1996; Misra et a.l., 1997). In some potatoes cultivars it was verified that $\mathrm{NaCl}$ induced a decrease of protein concentration, while at the same conditions, other ones showed an increase of proteins. The increase of proteins was associated with salt tolerance (Sasikala \& Prasad, 1994). In the present work, there was an increase of protein concentration in salt treated $H$. bonariensis and three bands desappeared and one appeared in $F$. vulgare.
The sandy soils from the two coastal localities showed great difference in salt concentration, probably due to the frequency of flood tide and rain incidence, leaching the soil profile. It was difficult to compare the concentrations of $\mathrm{NaCl}$ used in our experiments with the values found in the soil analyses. A mixture of sand and water (1:1) indicated for the Ubatuba sand soil a value much lower than the $\mathrm{NaCl}$ concentrations used in this work. Alternatively, it must be considered that the conductivity might not be exclusively due to $\mathrm{NaCl}$ presence, since other ions present in the soil might have interfered.

Although death occurred with both species growing in $\mathrm{NaCl}$ solutions, plants of $H$. bonariensis lasted longer at the higher $\mathrm{NaCl}$ concentration than $F$. vulgare. Some halophytes grow better in saline environment. Armeria maritima grew better at $40 \mathrm{mM} \mathrm{NaCl}$ than with salt-free treatment and survived several months at $200 \mathrm{mM} \mathrm{NaCl}$ (Khol, 1997). Other halophytes do not need salt to grow, but are salt-tolerant species. Plants of Phillyrea species (Oleaceae family) survived 4 months at $500 \mathrm{mM} \mathrm{NaCl}$ and showed the first signs of injury in the leaves at concentration of $750 \mathrm{mM} \mathrm{NaCl}$ (Gucci et al., 1997). On the other hand, Olea species, which belongs to the same family of Phillyrea, showed shoot growth inhibition at $100 \mathrm{mM} \mathrm{NaCl}$ (Gucci et al., 1997). It was concluded that species of Phillyrea were found in saline soils because they could tolerate better the salt presence than Olea sp. 
The occurrence of $H$. bonariensis in coastal regions may be determined by its capacity to tolerate saline environment, since this species has a large distribution, also growing in non saline soils. Therefore, it seems that $\mathrm{NaCl}$ is not essential for its growth. However, it is not possible to conclude from data of this work that $H$. bonariensis does not grow better with salt, since only two salt concentrations were used, which may be considered high when compared to other reports in the literature. Other experiments using lower salt concentrations have to be carried out to answer this question.

\section{ACNOWLEDGEMENTS}

The authors thank Instituto Agronômico de Campinas for the seeds of $F$. vulgare, Dr. J.T. Prisco for helpful comments and Claudia Magalhães for soil sample from São Sebastião. P.M thanks CNPq for a research fellowship. This work was financially supported by FAEPUnicamp.

\section{RESUMO}

Foi estudada a senescência de folhas, induzida por cloreto de sódio, em Hidrocotyle bonariensis Lam. e Foeniculum vulgare L. Ambas as espécies pertencem à família Umbellifera. Contudo, somente $H$. bonariensis cresce espontaneamente em solos arenosos da região costeira (solos salinos). Foram verificadas a massa fresa, massa seca e concentração de clorofila de folhas de plantas recebendo soluções de $\mathrm{NaCl}$ com diferentes concentrações. $\mathrm{O}$ perfil eletroforético denaturante de proteínas das folhas também foi avaliado. Aplicação de cloreto de sódio levou a alterações no perfil protéico de $F$. vulgare e acelerou a senescência das folhas das duas espécies. Todavia, plantas de H. bonariensis recebendo soluções de $\mathrm{NaCl}$ com $599 \mathrm{mM}$ sobreviveram mais tempo que as de $F$. vulgare. Assim a ocorrência de $H$. bonariensis em solos salinos pode estar relacionada a mecanismos de tolerância à salinidade.

\section{REFERENCES}

Abd el-Samad, H. M. \& Shaddad, M. A. K. (1997), Salt tolerance of soybean cultivars. Biol. Plant., 39, p.263-269

Bataglia, O. C.; Teixeira, J. P. F.; Furlani, P. R.; Furlani, A. M. C. \& Gallo, J. R. (1978), Métodos de análise química de plantas. Boletim Técnico do Instituto Agronômico de Campinas, 87

Bradford, M. M. (1976), A rapid and sensitive method for the quantitation of microgram quantities of protein utilizing the principle of protein dye binding. Ann. Biochem.,72, 248-254

Gucci, R.; Arone, G.; Lombardini, L. \& Tattini, M. (1977), Salinity tolerance in Phillyrea species. New Phytol.,135, 227-234

Jackson, M. B. \& Drew, M. C. (1984), Effects of flooding on growth and metabolism of herbaceous plants. In: Flooding and plant growth. Academic Press, New York, pp.47-111

Helmy, Y. H.; El-Abd, S. O.; Abou-Hadid, A. F.; El-Beltagy, M \& El-Beltagy, A. S. (1994), Ethylene production from tomato and cucumber plants under saline conditions. Egyptian J. Hort., 21, 153-160

Hoagland, D. R. \& Arnon, D. I. (1938), The water-culture method for growing plants without soil. University of California Agricultural Experimental Station, Circ. 347

Kohl, K. I. (1997), The effect of $\mathrm{NaCl}$ on growth, dry matter allocation and ion uptake in salt marsh and inland populations of Armeria maritima. New Phytol., 135, 213-225

Laemmlli, V. K. (1970), Cleavage of structural proteins during the assembly of the head of bacteriophage T4. Nature, 227, 680-685

Leopold, A. C. \& Kriedmann, P. E. (1975), Plant growth and development. Mc Graw Hill, New York

Lichtenthaler, H. K. \& Wellburn, A. R. (1983), Determination of total carotenoids and chlorophylls $\mathrm{a}$ and $\mathrm{b}$ of leaf extracts in different solvents. Biochem. Soc. Transactions, 11, 591-592

Lutts, S.; Kinet, J. M. \& Bouharmont , J. (1996), $\mathrm{NaCl}$-induced senescence in leaves of rice 
(Oriza sativa L.) cultivars differing in salinity resistance. Ann. Bot., 78, 389-398

Matile, P.; Duggelin, T.; Schellenberg, M.; Rentsch, D.; Bortlik, K.; Peisker, C. \& Thomas, S. H. (1989), How and why is chlorophyll broken down in senescent leaves? Plant Physiol. and Biochem., 27, 595-604

Matile, P.; Schellenberg, M. \& Peisker, C. (1992), Production and release of a chlorophyll catabolite in isolated senescent chloroplast. Planta, 187, 230-235

Mc Intyre, F. (1982), Por que el mar es salado.In- Oceanografia, H. Blume Ediciones, Madri.

Misra, A. N.; Sahu, S. M.; Misra, M.; Singh, P.; Meera, I.; Das, N.; Kar, M. \& Sahu, P. (1997), Sodium chloride induced changes in leaf growth, and pigment and protein contents in two rice cultivars. Biol. Plant., 39, 257-262

Munns, R.; Schachtman, D. P. \& Condon, A. G. (1995), The significance of a two-phase growth response to salinity in wheat and barley. Aust. J. Plant Physiol., 22, 561-569

O'Leary, J. W. \& Prisco, J. T. (1970a), Response of osmotically stressed plants to growth regulators. Adv. Front. Plant. Sci., 25, 129-139

O'Leary, J. W. \& Prisco, J. T. (1970b), Effect of salt and water stresses on protein synthesizing capacity of embryo-axis of germinating Phaseouls vulgaris L. seeds. Rev. Brasil. Biol., 30, 317-21

Prisco, J. T. (1971), Polyacrylamide gel electrophoresis of soluble proteins of salt and water stressed embrio-axis of Phaseolus vulgaris L. seeds during germination. Cien. Agron., 1, 47-50
Prisco, J. T. \& O' Leary, J. W. (1972). Enhancement of intact bean leaf senescence by $\mathrm{NaCl}$ salinity. Physiol. Plant., 2, 95-100

Prisco, J. T. (1980), Alguns aspectos da fisiologia do "stress" salino. Rev. brasil. Bot., 3, 85-94

Sasikala, D. P. P. \& Prasad, P. V. D. (1994), Salinity effects on in vitro performance of some cultivars of potato. Rev. Bras. Fisiol. Veg., 6, 1-6

Sharma, S. K. (1996), Soil salinity effects on transpiration and net photosynthetic rates, stomatal conductance and $\mathrm{Na}+$ and $\mathrm{Cl}-$ contents in durum wheat. Biol. Plant., 38, 519-523

Singh, N. K.; La Rosa, P. C.; Handa, A. K.; Hasegawa, P. M. \& Bressan, R. A. (1987), Hormonal regulation of protein synthesis associated with salt tolerance in plant cells. Proc. Natl. Acad. Sci. USA, 84, 739-743

Smart, C. M. (1994), Gene Expression during leaf senescence. New Phytol., 126, 419-448

Thomas, H.; Cugham, H. J \& Davies, T. G. E. (1992), Leaf senescence in a non yellowing mutant of Festuca pratensis. Transcripts and translation products. J. Plant Physiol., 139, 403-412

Wainwright, S. J. (1984), Adaptations of plants to flooding with salt water In: Flooding and plant growth. Academic Press, New York, pp.295-334

Yamaoka-Yano, D. M. \& Mazzafera, P. (1998), Degradation of caffeine by Pseudomonas putida isolated from soil under coffee cultivation. Allelopathy Journal, 5, 23-34.

Received: March 14, 1998; Revised: August 25, 1998; Accepted: May 05, 1999. 